P̈roc. Ëstonian Acad. Sci. Geol., 1996, 45, 2, 53-67

\title{
HYDROGEOLOGICAL MODELLING OF MINE DEWATERING IN THE KARSTIFIED PANDIVERE UPLAND, ESTONIA
}

\author{
Leo VALLNER
}

Eesti Geoloogiakeskus (Geological Survey of Estonia), Kadaka tee 80/82, EE-0026 Tallinn, Eesti (Estonia)

Received 31 July 1995, accepted 18 December 1995

\begin{abstract}
The site of the proposed Kabala oil shale mine is located on the slope of the Pandivere Upland which is composed of significantly karstified carbonate bedrock. The quasi-three-dimensional transient groundwater flow modelling revealed that the maximum pumping rate for the dewatering of the underground mine would be $96000-160000 \mathrm{~m}^{3} / \mathrm{d}$ depending on vertical permeability of the mine roof. Mine dewatering would cause a drawdown of the groundwater table ranging from 0.5 to $40 \mathrm{~m}$ in an area of about $1000 \mathrm{~km}^{2}$. The aquatic environment may become heavily polluted.
\end{abstract}

Key words: hydrogeological modelling, mine dewatering, oil shale, carbonate bedrock, karst, Estonia.

\section{INTRODUCTION}

In 1986 the administration of the former Soviet Union started intensive preparations for large-scale mining of Nortil Estonian phosphorite in the Pandivere Upland. As the phosphorite is there overlain by a commercial oil shale layer, it was recommended to extract the oil shale before the mining of phosphorite. Owing to the disintegration of the Soviet Union, this project was not put into practice. However, many thorough investigations were carried out in connection with the mining planned. They provided a lot of new experimental data and technological ideas which may be useful for the future development of Estonian minerals (Пуура et al., 1987).

Problems of the dewatering of the proposed Kabala oil shale mine were studied by hydrogeological modelling at the Institute of Geology, Estonian Academy of Sciences, until 1993. This paper describes the model developed and results of simulations carried out.

\section{STUDY AREA}

The area under consideration covers $1170 \mathrm{~km}^{2}$ in the Pandivere Upland and adjacent North Estonian Plateau (Figs. 1, 2). The mostly flat Upland rises $70-130 \mathrm{~m}$ above sea level. The surrounding Plateau has commonly a low slightly dissected topography with absolute altitudes from 40 to $70 \mathrm{~m}$. The Kabala mine site, covering $43 \mathrm{~km}^{2}$, is situated on the northeastern slope of the Upland between the Selja and Kunda rivers where altitudes range predominantly from 70 to $85 \mathrm{~m}$. 


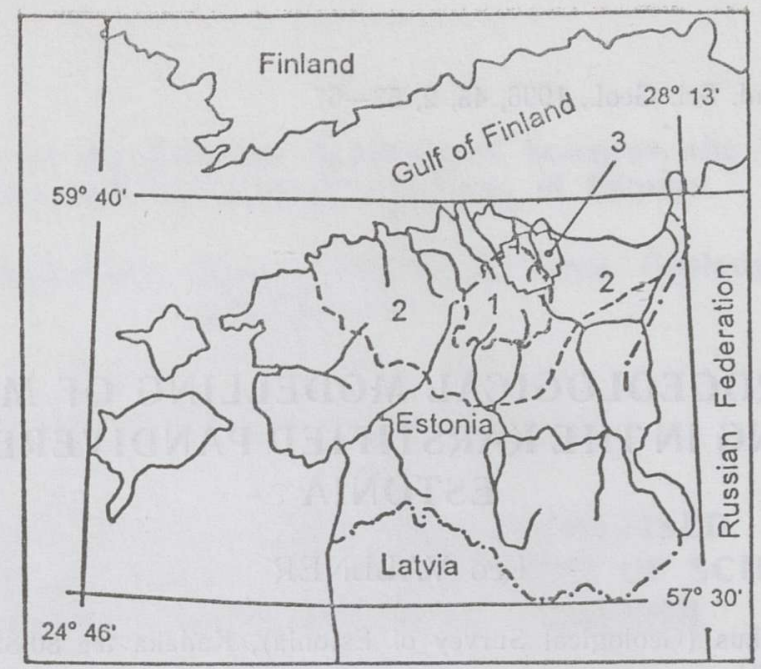

Fig. 1. Location map. 1, Pandivere Upland; 2, North Estonian Plateau; 3, study area.

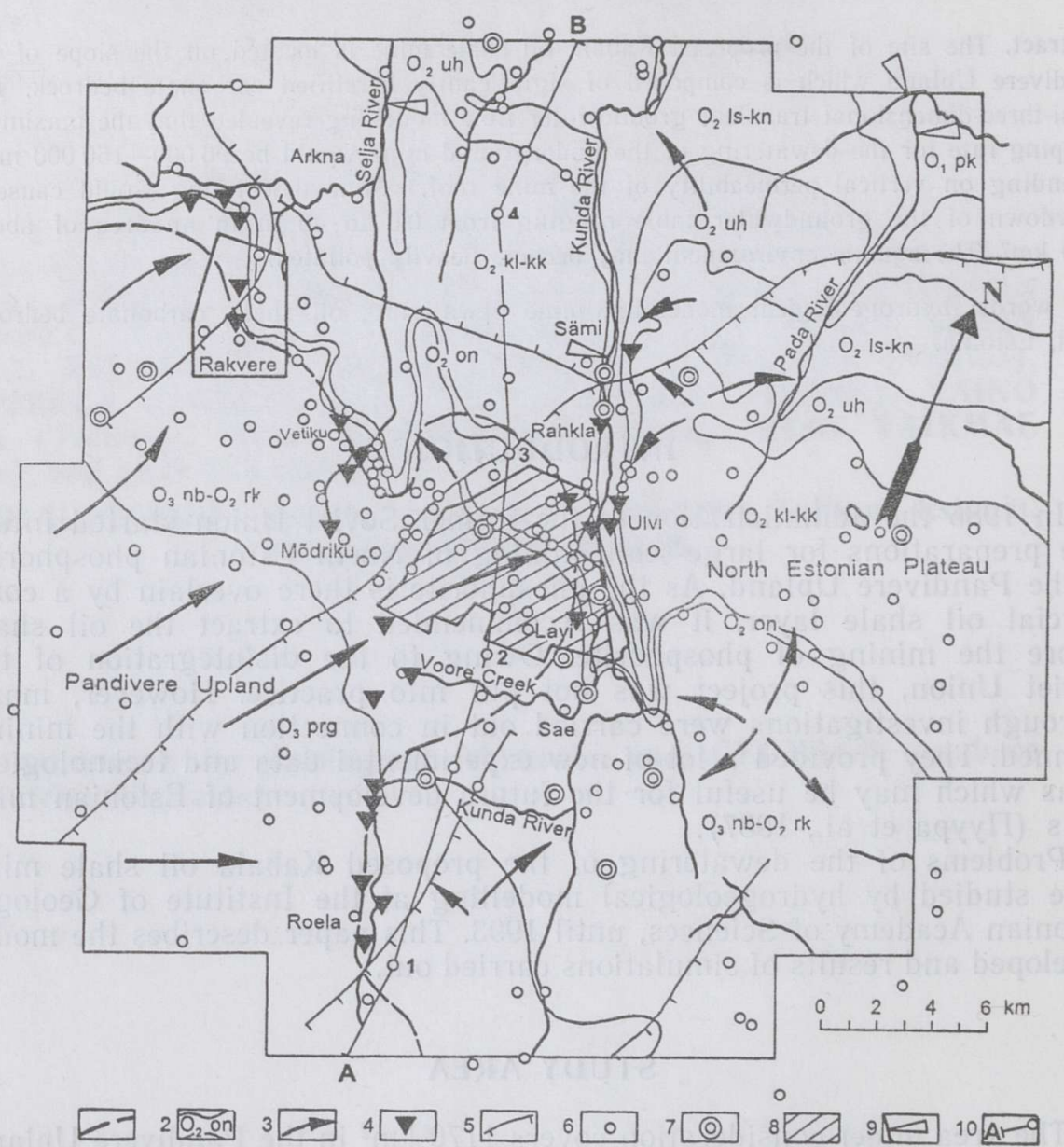

Fig. 2. Hydrogeological map of the study area. 1, boundary between the Pandivere Upland and North Estonian Plateau; 2, outcrop of a hydrogeological unit and its index; 3 , direction of groundwater movement; 4 , spring; 5 , tectonic dislocation; 6 , hydrogeological pumping well; 7 , long-time observation well; 8 , Kabala mine site; 9, hydrological gauging station; 10 , hydrogeological cross-section. 
The mean annual air temperature is about $4{ }^{\circ} \mathrm{C}$ in the study area. Average monthly air temperatures range from $-7.5^{\circ} \mathrm{C}$ in February to $+16.5^{\circ} \mathrm{C}$ in July. The mean annual precipitation varies in between $700-$ $750 \mathrm{~mm}$.

The Quaternary sediments consist mostly of sandy or loamy till which in places is covered by glaciofluvial gravels and sands. There are many mires around the Upland. The thickness of Quaternary sediments does not commonly exceed 5-10 $\mathrm{m}$, but it reaches $60-70 \mathrm{~m}$ in the buried valley of the Kunda River.

The Quaternary cover lies on the Silurian and Ordovician fissured limestones and dolomites interbedded with marls (Fig. 3). Their total thickness is $20-120 \mathrm{~m}$. Below the carbonate bedrock formation come Cambrian and Upper Proterozoic sandstones, siltstones, and clays averaging $170 \mathrm{~m}$ in total thickness. The layers of sedimentary bedrock dip southwards at 3-4 m per $1 \mathrm{~km}$ overlying the Lower Proterozoic crystalline basement.

The upper portion of carbonate bedrock is significantly karstified and cavernous to the depth of $30 \mathrm{~m}$ from its surface. Below a depth of $70 \mathrm{~m}$ the fissures and karst openings are almost closed or sealed in Silurian and Ordovician strata. The Oandu Stage $\left(\mathrm{O}_{2} \mathrm{On}\right)$, represented chiefly by 1-4-m-thick marl, is the uppermost effective aquitard in the bedrock (Перенс, 1984; Валлнер et al., 1987). The Oandu aquitard is overlain by the Pirgu $\left(\mathrm{O}_{3}\right.$ prg) and Nabala-Rakvere $\left(\mathrm{O}_{3} \mathrm{nb}-\mathrm{O}_{2} \mathrm{rk}\right)$ unconfined aquifers consisting of fissured limestones and dolomites. Their thickness grows from zero at the outcrop of the Oandu aquitard to $90 \mathrm{~m}$ at the southern border of the study area.

The next efficient aquitard of the carbonate bedrock is formed by the Uhaku Stage $\left(\mathrm{O}_{2} \mathrm{uh}\right)$ containing clayey interbeds in limestones. The

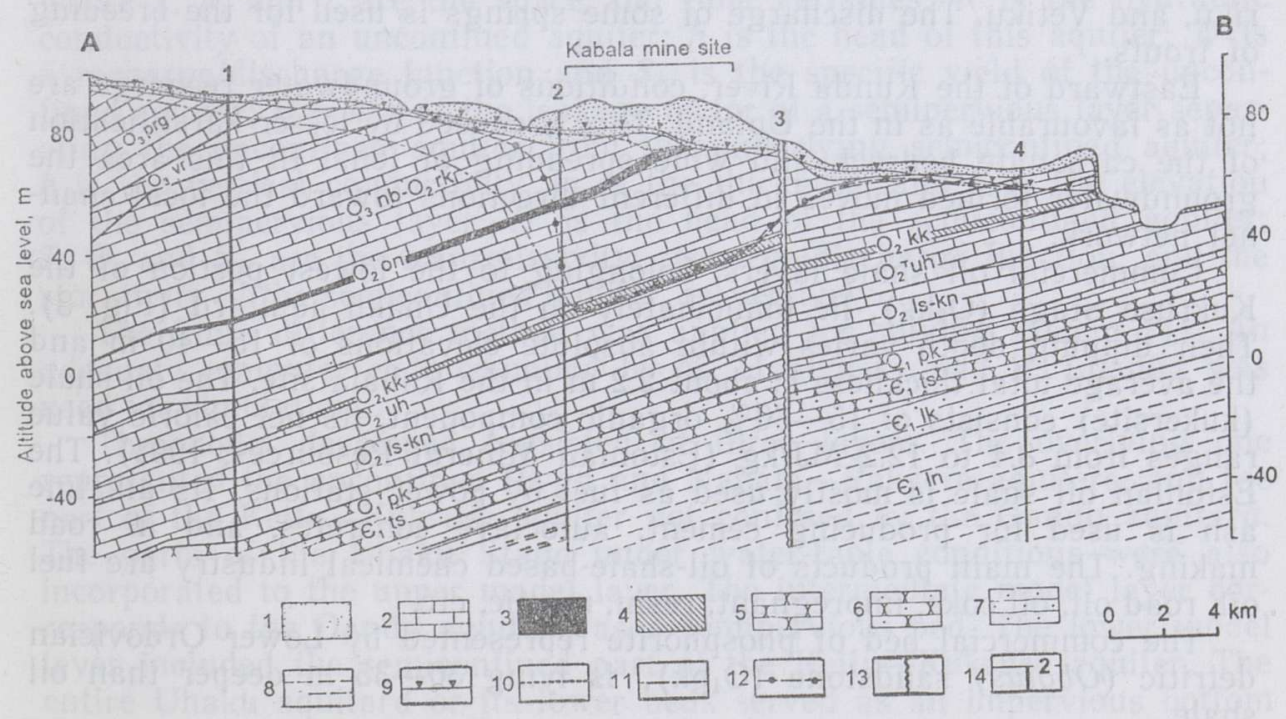

Fig. 3. Hydrogeological cross-section A-B. 1, Quaternary deposits: sand and gravel; 2, limestones and dolomites; 3 , marl; 4 , oil shale; 5 , sandstone containing phosphorite; 6 , siltstone; 7 , siltstone and clay; 8 , clay; 9 , groundwater table under predevelopment conditions; 10, groundwater table of the Nabala-Rakvere aquifer; 11, head of the KeilaKukruse aquifer in the 40 th mine dewatering year (scenario 1); 12, the same at scenario 2 ; 13 , tectonic dislocation; 14 , hydrogeological borehole. 
Uhaku layers, spreading on the most of the study area, are under the water-table conditions in their outcrop. Between the Oandu and Uhaku aquitards lies the Keila-Kukruse aquifer $\left(\mathrm{O}_{2} \mathrm{kl}-\mathrm{O}_{2} \mathrm{kk}\right)$ consisting of fissured limestones and dolomites interbedded by clayey limestones and marls. The thickness of this aquifer grows from zero in the northern part to 25 in the southern part of the area. The aquifer is only halfway confined by the semipervious Oandu aquitard. In the Upland the KeilaKukruse aquifer recharges from the overlying Nabala-Rakvere aquifer through Oandu beds. The difference between groundwater heads of these both aquifers reaches $10-15 \mathrm{~m}$ there. North of the outcrop of Oandu beds, the Keila-Kukruse aquifer is unconfined recharging directly by infiltration.

In the central part of the Upland, where the carbonate bedrock is most intensively karstified, the net infiltration rate (actual long-term groundwater recharge) is up to $280 \mathrm{~mm}$ per year or $9 \mathrm{l} /\left(\mathrm{s} \cdot \mathrm{km}^{2}\right)$ (ВаллHep, 1980). In this area almost all rain- and meltwater percolates into karst interstices. Due to the high permeability of the carbonate bedrock, the formed groundwater quickly discharges to adjacent streams. Therefore, the groundwater table is relatively deep in the Upland lying often $7-20 \mathrm{~m}$ below the ground surface. At such groundwater depth discharge by evaporation from the zone of saturation or capillary fringe is negligible. Consequently, the rivers with extensive catchment areas in the central part of the Upland are under most favourable recharging conditions. For this reason, the mean annual specific runoff rate of the Kunda River is $11.7 \mathrm{l} /\left(\mathrm{s} \cdot \mathrm{km}^{2}\right)$, while the same parameter averaged over the lowlands of Estonia does not exceed $8.5 \mathrm{l} /\left(\mathrm{s} \cdot \mathrm{km}^{2}\right)$.

In the study area the groundwater moves from the Upland toward the Selja and Kunda rivers (Fig. 2). The upper portion of this flow is discharged by numerous springs which are situated on the slopes of the Upland. The springs are commonly small, but the average annual yield of some of them reaches $20000-30000 \mathrm{~m}^{3} / \mathrm{d}$ at Lavi, Ulvi, Rahkla, Mõdriku, and Vetiku. The discharge of some springs is used for the breeding of trouts.

Eastward of the Kunda River, conditions of groundwater recharge are not as favourable as in the Upland. This is caused by lesser karstification of the carbonate bedrock and wide spreading of fens. In this area the groundwater formed moves in different directions toward the local channel network.

Commercial oil shale layers, belonging to the lowest portion of the Kukruse Stage $\left(\mathrm{O}_{2} \mathrm{kk}\right)$, lie immediately on the Uhaku aquitard (Fig. 3). Their dipping depth varies within absolute elevations of $15-40 \mathrm{~m}$ and the average total thickness is about $2.2 \mathrm{~m}$ in the Kabala site. The oil shale (kukersite) consists of $15-60 \%$ organic component, its net caloric value ranges from 8.4 to $12.2 \mathrm{MJ} / \mathrm{kg}$ (Estonian Mineral Resources, 1994). The Estonian oil shale is mostly used as fuel by power stations. Its alkaline ash is used for producing cement, autoclave concretes, and in road making. The main products of oil-shale-based chemical industry are fuel oil, road oil, oil coke, impregnant, resin, mastic, etc.

The commercial bed of phosphorite represented by Lower Ordovician detritic (Obolus) sandstone $\left(\mathrm{O}_{1} \mathrm{pk}\right)$, is lying $30-35 \mathrm{~m}$ deeper than oil shale.

The study area is mostly farmland or forest. The rural population, about 10000 persons in all, resides in farms or small settlements. The town of Rakvere has 20000 inhabitants. All drinking water for domestic and public supply is obtained from wells. Rakvere and many settlements have municipal bored wells, 80-150 m deep, tapping the carbonate bedrock or underlying sandstones. Dug or bored wells reaching a depth of up to $10-30 \mathrm{~m}$ are commonly used by rural households. The total amount 
of groundwater obtained from carbonate bedrock is about $4000 \mathrm{~m}^{3} / \mathrm{d}$ in the study area. Owing to agricultural activities, the shallow groundwater is polluted by nitrates. Therefore, in some places the rural population is facing problems with the drinking water (Vallner, 1994).

\section{GROUNDWATER FLOW MODEL}

Only underground mining of oil shale could be allowed in the Kabala site. In this way the damages of the natural scenery would be minimized.

The roadway of the underground mine should coincide with the top of the Uhaku aquitard. The height of the goaf should be equal to the thickness of commercial oil shale layers, i.e. $2.2 \mathrm{~m}$ on average. In that case the mine roof will consist of fissured carbonate bedrock, $30-35 \mathrm{~m}$ thick (Fig. 3 ). Driving of roads and mining should be started at the southern border of the site and extended northwards. Due to the southward dip of layers, the minewater gathered by roadway ditches will flow under gravity into main sumps for pumping to the ground surface. For the dewatering of the mine, the groundwater head of the Keila-Kukruse aquifer must be withdrawn by $35-60 \mathrm{~m}$ as low as the top of the Uhaku aquitard.

The pumping rate of minewater and the impact of mine dewatering on the aquatic environment were studied by hydrogeological modelling (Anderson \& Woessner, 1992; van der Heijde \& Elnawawy, 1993). To that end, a transient quasi-three-dimensional distribution of the groundwater head was imitated by the following system of differential equations:

$$
\left\{\begin{array}{l}
\frac{\partial}{\partial x}\left[K(h-b) \frac{\partial}{\partial x}\right]+\frac{\partial}{\partial y}\left[K(h-b) \frac{\partial}{\partial y}\right]-B(h-H)+W=S_{h} \frac{\partial h}{\partial t} \\
\frac{\partial}{\partial x}\left(T \frac{\partial H}{\partial x}\right)+\frac{\partial}{\partial y}\left(T \frac{\partial H}{\partial y}\right)+B(h-H)+Q=S_{H} \frac{\partial H}{\partial t}
\end{array}\right.
$$

where $x, y$, and $t$ are the space and time variables; $K$ is the hydraulic conductivity of an unconfined aquifer; $h$ is the head of this aquifer; $W$ is a recharge/discharge function and $S_{h}$ is the specific yield of the unconfined aquifer; $B=k / m$ is the leakage factor of a semipervious layer separating the unconfined aquifer from the underlying semiconfined aquifer; $k$ is the vertical conductivity, $m$ is the thickness, and $b$ is the elevation of the semipervious layer; $H$ is the head of the semiconfined aquifer; $T, Q$, and $S_{H}$ are the transmissivity, recharge/discharge function, and the storativity of the semiconfined aquifer, respectively.

The finite difference method was applied for solving system (1). An adequate computer code compiled by $M$. Hvalynsky and V. Lifshitz was used for simulations.

The model developed consisted of three layers. The overlying one represented the unconfined Pirgu and Nabala-Rakvere aquifers, and the part of the Keila-Kukruse aquifer not confined by the Oandu aquitard. The parts of the Uhaku Stage under water-table conditions were also incorporated to the upper model layer. The intermediate model layer corresponds to the Oandu aquitard as a semipervious bed. The lower model layer included the semiconfined part of the Keila-Kukruse aquifer. The entire Uhaku aquitard or its lower beds served as an impervious bottom of the modelled groundwater system. Actually the Uhaku beds are semipervious, but their low vertical permeability may be neglected at mine dewatering (Газизов, 1971; Норватов, 1988).

The study area was covered with a rectangular grid for finite-difference discretization. The grid consisted of 26 columns and 27 rows forming 658 active blocks. Sizes of blocks ranged from $600 \times 600 \mathrm{~m}$ in the central part of the area to $2500 \times 2500 \mathrm{~m}$ on its outskirts (Fig. 2). 
The data used for modelling were mostly derived from research reports prepared by the Geological Survey of Estonia (Перенс, 1978, 1984; Раудceп et al., 1989; Саадре et al., 1984; etc.). The results of 182 time-drawdown and distance-drawdown aquifer tests were used to characterize the permeability of water-bearing strata (Fig. 2). The hydraulic conductivity $K$ of the overlying model layer was estimated to be mostly from 10 to $80 \mathrm{~m} / \mathrm{d}$. The $K$ value did not exceed $5 \mathrm{~m} / \mathrm{d}$ in a poorly drained area eastward of the Kunda River. The transmissivity of the lower model layer ranged only from 12 to $24 \mathrm{~m}^{2} / \mathrm{d}$ in the southern part of the study area characterized by the typical low permeability of the deeper portion of the Keila-Kukruse aquifer. The transmissivity of the lower model layer increased up to $100-300 \mathrm{~m}^{2} / \mathrm{d}$ toward the outcrop of the Oandu aquitard. The specific yield $S_{h}$ of the upper unconfined layer ranged from $3.3 \times 10^{-4}$ to $1.6 \times 10^{-1}$. The range in the storage coefficient $S_{H}$ of the lower semiconfined layer was $3.4 \times 10^{-7}$ to $3.0 \times 10^{-4}$.

In the study area a hydrological gauging station has been operating on the Kunda River at Sämi since 1942 (Fig. 2). Two other stations have been acting on the Pada River since 1979 and one operated on the Selja River at Arkna from 1932 to 1959. The discharge of 17 springs was measured at special gauging stations during several years. Apart from the gauging stations, many irregular measurements of the low flow have been made in 53 stream cross sections during dry summer periods since 1959. The gained sporadic low flow data were modified to the average base flow value by statistical methods using regular observations of gauging stations.

Groundwater levels measured during pumping tests of hydrogeological boreholes as well as altitudes of the streamwater table estimated from topographic maps served for determining the hydraulic head distribution in the study area. Additional data were obtained from well-construction records and reports of hydrogeological mapping.

In most points the head was measured one or only several times between 1950-1993. Regular head observations with the duration from 1 to 18 years were carried out only in 15 boreholes. Asynchronous data reflecting secular and seasonal variations of climatic conditions could not be directly used at the modelling. Therefore, the heads determined sporadically, were modified to a long-term mean, mean highest, and mean lowest groundwater level for each measuring point. The generalized graphs of groundwater level fluctuation, based on the results of the statistical treatment of many regular observations made in the North Estonian Plateau and Pandivere Upland, were used for this purpose (Vallner, 1982). Sporadically observed groundwater levels were modified by means of adjustment factors determined from generalized graphs depending on the measuring data of levels. The mean absolute error of modified heads ranged from $\pm 0.5 \mathrm{~m}$ (in the area of mires) to $\pm 1.5 \mathrm{~m}$ (in the Pandivere Upland). Maps of mean and extremal groundwater levels were completed proceeding from modified heads.

Specified rates of subsurface fluxes assigned to model lateral boundaries were calculated using the head gradients determined from the average groundwater level. The inflow was estimated along the western and southern boundaries. The outflow occurred along the northern and eastern model boundaries.

A preliminary groundwater budget of the modelled layers was compiled using the modified base flow data and calculated values of subsurface fluxes through the model boundaries. The total infiltration $R$ was determined from the water budget equation: 


$$
R=D+P+E-G-F \pm C,
$$

where $D$ is the groundwater discharge (base flow) to streams; $P$ is the pumpage from water supply wells; $E$ and $G$ are the subsurface outflow and the inflow through the model lateral boundaries, respectively; $F$ is the flow from streams into aquifers; $C$ is the storage change.

In this way the groundwater budget was compiled without estimating the evapotranspiration. However, to control the results obtained by Eq. (2), the actual evapotranspiration $V$ was determined from standard meteorological measurements (Lerner et al., 1990). The calculated values of $V$ were used for estimating the infiltration $R$ from another water budget equation:

$$
R=N-M-V-E-P+G+F \pm C,
$$

where $N$ is the precipitation; $M$ is the surface runoff; $E, P, G, F$, and $C$ are defined below Eq. (2).

The relative difference between the values of $R$ obtained by Eqs. (2) and (3) did not exceed $25 \%$, but for modelling the data gained by Eq. (2) were preferred. It was supposed that a water budget controlled by direct base flow measurements was more authentic than the one grounded on the calculated evapotranspiration data.

The infiltration rate was specified assuming that a base flow increment in a portion of the channel network corresponded to the actual infiltration in the subsurface catchment area of this network. The impact of the lateral boundary conditions on the forming of the streamflow was taken into account, too. The subsurface catchment areas were determined from groundwater-table and potentiometric-surface maps.

Mixed boundary conditions were assigned to all lateral sides of the model. This made it feasible to compute subsurface lateral fluxes as functions of the difference between the computed head in a grid boundary block and an assumed recharge or discharge head outside the boundary.

Streams were represented also by mixed boundary conditions. This enabled us to compute head-dependent fluxes between streams and aquifers, which was very important for the study of mine dewatering. The streambed conductance was not determined by pumping tests in the area under consideration. However, it was calculated by the formula:

$$
c=q(r-h)^{-1},
$$

where $c$ is the streambed conductance, $q$ is the base flow runoff, $r$ is the altitude of the stream surface, and $h$ is the head of the unconfined aquifer. Values of the base flow runoff for certain portions of the channel network were determined by irregular measurements of low flow rates and heads were gained from the groundwater-table map.

\section{MODEL CALIBRATION}

Sums of modified mean heads and their errors in measuring points were used as model calibration targets. Besides the modifying error of asynchronous data, an inexactness caused by interpolation of water level measurements to the closest model node was taken into account. Therefore, the mean error of the head estimation ranged from \pm 1 to $\pm 2 \mathrm{~m}$ in grid nodes. Modified base flow rates served as additional calibration targets. Their relative errors varied from \pm 10 to $\pm 15 \%$.

A conception of calibration levels was used for evaluation of calibration accuracy (Woessner \& Anderson, 1990). Three calibration levels were distinguished: (1) simulated value fell within a calibration target, (2) simulated value fell within two times, and (3) it fell within three 
times the target. A model value calibrated to level 1 was considered as the highest level of calibration. Levels 2 and 3 corresponded to the medium and lower degree of calibration, respectively.

Calibration was carried out using the trial-and-error adjustment for achieving the optimum match between simulated parameters and calibration targets. At the steady-state model calibration conductivity of layers and infiltration rates were corrected by $20 \%$ - in some model localities. Leakage factor and streambed conductance, preliminarily not determined by pumping tests, needed more profound correction than lateral conductivity. The calibration indicated that the values of the leakage factor $B$ characterizing the Oandu aquitard ranged from $1.5 \times 10^{-5}$ to $2.0 \times 10^{-4} \mathrm{l} / \mathrm{d}$ in the arch of the Pandivere Upland. On the outskirts of the outcrop of the aquitard, the $B$ value varied from $7.5 \times 10^{-4}$ to $2.1 \times 10^{-2} \mathrm{l} / \mathrm{d}$. The calibrated streambed conductance $c$ ranged between $2.0 \times 10^{3}$ and $5.0 \times 10^{4} \mathrm{~m}^{2} / \mathrm{d}$.

The highest and medium calibration levels were mostly achieved by steady-state model calibration (Table 1). Corrections of hydrogeological parameters introduced by model calibration remained within acceptable ranges. Simulated head distribution reflected the draining effect of streams in details matching with groundwater-table maps completed in a traditional way.

Based on the calibrated steady-state model, the distributions of heads $h(x, y)$ and $H(x, y)$ were simulated. They were considered as mathematically correct descriptions of initial conditions for the transient model. To calibrate the transient model, the long-term mean annual value of $W(x, y, t)$, estimated in accordance with total infiltration $R$, was modified on average by $\pm 30 \%$ during a generalized computational year. The calculated average monthly values of $W(x, y, t)$ were assigned to the nodes of the upper model layer. As a result, the simulated values of functions $h(x, y, t)$ and $H(x, y, t)$ varied in the course of the computational year fitting more or less the calculated average long-term fluctuation of groundwater heads in observation wells. To get a better accordance between the observed and simulated heads, in places the specific yield and the storage coefficient of model layers were corrected up to $30 \%$.

Modified extremal heads and their errors calculated for observation wells served as transient calibration targets. Whereas the mean annual amplitude of the groundwater-table fluctuation ranged from $1 \mathrm{~m}$ in peatlands to $4 \mathrm{~m}$ in the Pandivere Upland, the transient calibration was more difficult to carry out than the steady-state one. Nevertheless, the medium calibration level was mostly achieved (Table 1).

Table 1

Results of steady-state model calibration

\begin{tabular}{|c|c|c|c|}
\hline \multirow[t]{2}{*}{$\begin{array}{l}\text { Calibration target (estimated for the closest } \\
\text { model node to an observation point) }\end{array}$} & \multicolumn{3}{|c|}{$\begin{array}{l}\text { Calibration criterion (numerator); } \\
\text { percent of nodes falling within a } \\
\text { given level (denominator) }\end{array}$} \\
\hline & Level 1 & Level 2 & Level 3 \\
\hline $\begin{array}{l}\text { Groundwater table of the upper model layer, } \\
168 \text { nodes }\end{array}$ & $\frac{ \pm 2 \mathrm{~m}}{78}$ & $\frac{ \pm 4 \mathrm{~m}}{22}$ & $\frac{ \pm 8 \mathrm{~m}}{0}$ \\
\hline Head of the lower model layer, 98 nodes & $\frac{ \pm 1 \mathrm{~m}}{86}$ & $\frac{ \pm 2 \mathrm{~m}}{14}$ & $\pm \frac{3 \mathrm{~m}}{0}$ \\
\hline $\begin{array}{l}\text { Baseflow rate, } 74 \text { nodes (calibration criterion: } \\
\text { mean relative error of a modified value) }\end{array}$ & $\frac{ \pm 10 \%}{71}$ & $\frac{ \pm 20 \%}{29}$ & $\frac{ \pm 30 \%}{0}$ \\
\hline
\end{tabular}


Results of both steady-state and transient calibrations indicated that the groundwater flow model completed was suitable for simulation of oil shale mine dewatering.

The steady-state water budget expressing the predevelopment conditions of the study area was simulated using the fully calibrated model. It became evident that the modelled groundwater system recharged mainly from infiltration and discharged to streams (Table 2). The portions of subsurface fluxes through the lateral model boundaries formed only $4-12 \%$ of the total infiltration. The given downward flux through the bottom of the Uhaku aquitard reaching $19000 \mathrm{~m}^{3} / \mathrm{d}$ was estimated using the former groundwater budget investigations.

Table 2

Long-term groundwater budget of the study area in predevelopment conditions (round numbers), $\mathrm{m}^{3} / \mathrm{d}$

\begin{tabular}{c|c}
\hline Inflow & Outflow \\
\hline
\end{tabular}

$\begin{array}{lrlr}\text { Total infiltration } & 651000 & \text { Evapotranspiration from groundwater table } & 385000 \\ \text { Lateral subsurface flux } & 76000 & \text { Discharge to streams } & 308000 \\ \text { Recharge from streams } & 16000 & \text { Lateral subsurface flux } & 27000 \\ & & \text { Pumping } & 4000 \\ & & \text { Downward flux through the Uhaku aquitard } & 19000 \\ & 743000 & \text { Total } & 743000\end{array}$

\section{IMPACT OF MINE DEWATERING}

To predict the impact of mine dewatering on the aquatic environment, it was assumed that the groundwater pumping should be started at the middle of the southern border of the Kabala site where the mine bottom and the main sump would be constructed. The underground mining should last $30-40$ years until the total extraction of the commercial oil shale layers. It was postulated for simulations that three quarters of the mine area had to be dewatered during 25 years after the start of the pumping.

The functions $h(x, y), H(x, y), W(x, y)$, determined by steady-state modelling, were used as initial conditions for the transient model. To simulate the dewatering, technically possible pumping rates $Q(x, y, t)$ were assigned to the model nodes in the southern part of the mine site. Pumping rates were gradually shifted northwards in accordance with supposed progressing of the mining.

The mine dewatering was simulated for two eventual scenarios which enabled to evaluate the effect of the state of the Oandu aquitard on the dewatering.

Scenario 1. It was assumed that the parameters, specified by both the steady-state and transient model calibrations, adequately represented the groundwater system under consideration. In that case, at a constant pumping rate of $35000 \mathrm{~m}^{3} / \mathrm{d}$, the needed drawdown of groundwater heads will be obtained on the outskirts of the mine bottom in the second dewatering year. If the pumping is continued with the same intensity, the dewatered mine portion will widen to the distance of $1-2 \mathrm{~km}$ from the mine bottom in five years. Approximately a half of the mine site (its southern part) will be dewatered during ten years after the pumping 
begins, but to achieve this aim, the pumping rate must be raised to $74000 \mathrm{~m}^{3} / \mathrm{d}$ between the 5 th and 10 th dewatering years. If the pumping rate is increased to $82000 \mathrm{~m}^{3} / \mathrm{d}$ from the 10 th year onwards, then about four-fifths of the mine site will be dewatered in the 30th pumping year. The discharge of water into the mine will be most intensive at the Kunda River. Special measures preventing the eventual cascading of river water into the goaf should be foreseen there.

The dewatering of the Kabala oil shale mine will cause a depressurization of the confined portion of the Keila-Kukruse aquifer (Fig. 4). The depression of $10 \mathrm{~m}$ will extend in the southwestern direction to the distance of $5-7 \mathrm{~km}$ from the mine site in the 40 th year of dewatering. The drawdown of the pressure will be 3-4 $\mathrm{m}$ at the southern and southwestern boundaries of the study area.

The water table of the unconfined portion of the Keila-Kukruse aquifer and upper beds of the Uhaku Stage will lower in the area between the Kunda and Selja rivers. The groundwater table will be withdrawn by up to $30-40 \mathrm{~m}$ and the mine roof will be completely dewatered there. However, the depression of groundwater table will gradually decline northwards. At Kohala it will not exceed 0.5-1 m.

The portion of the Nabala-Rakvere aquifer, overlying the Oandu

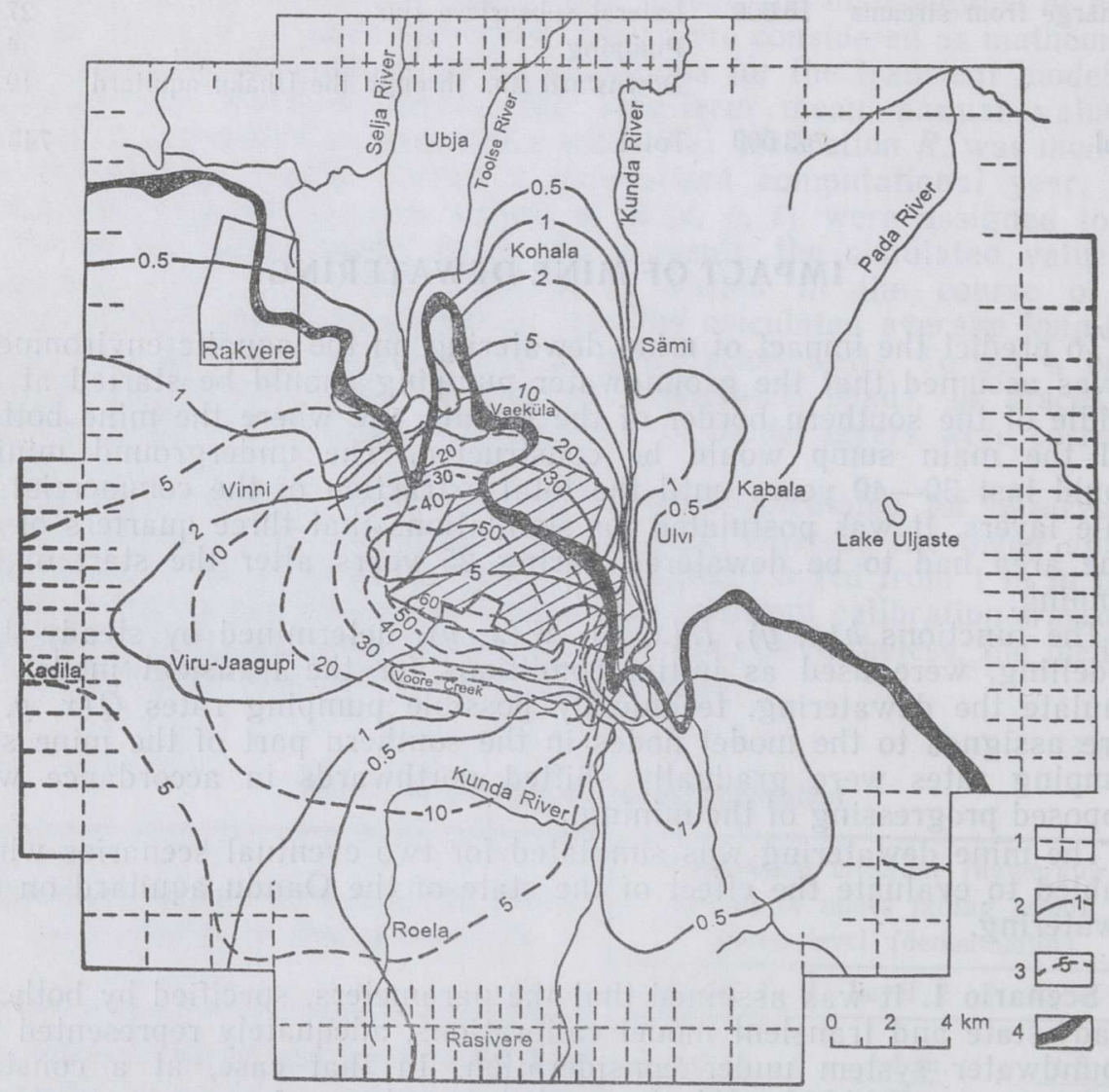

Fig. 4. Drawdown in groundwater level in the 40 th dewatering year. 1, grid of finitedifference discretization (only the peripheral portion of the grid shown); 2, drawdown contour in the groundwater table of the Nabala-Rakvere and Keila-Kukruse aquifers, $\mathrm{m}$; 3, drawdown contour in the head of the Keila-Kukruse aquifer, m; 4, outcrop of the Oandu aquitard. 
aquitard in the Kabala mine site, will be dewatered partially. The water table of this aquifer will drop by $2-10 \mathrm{~m}$. Outside the mine site, the drawdown of the water table reaching up to $2 \mathrm{~m}$ will expand to the distance of $10 \mathrm{~km}$ in the southwestern direction. The depression of the groundwater table in the Pirgu and Nabala-Rakvere aquifers equalling to $0.5 \mathrm{~m}$ will spread in the whole eastern part of the Pandivere Upland.

The Kunda River will serve as a recharge boundary at the mine dewatering. On the other hand, the ancient valley of this stream buried by loamy till will restrict the spreading of the drawdown along deeper layers eastwards of the mine site. Therefore, the groundwater table will lower only by $1-2 \mathrm{~m}$ in the right-bank area of the Kunda River.

A complete dewatering of the Kabala oil shale mine will cause a decrease in the groundwater discharge to streams by $100000 \mathrm{~m}^{3} / \mathrm{d}$ in the whole study area. The most significant streamwater losses, in total reaching $90000 \mathrm{~m}^{3} / \mathrm{d}$, will occur in the Voore Creek and in the Kunda River between Sae and Sämi. The discharge of the Lavi Spring will decline by $10000 \mathrm{~m}^{3} / \mathrm{d}$, and many minor springs between Lavi and Sämi will dry up. The runoff rate of the Kunda River may lessen to a half upstream from Sämi in the summer or winter low flow periods. The groundwater discharge to the upstream of the Selja River will decrease by $15000 \mathrm{~m}^{3} / \mathrm{d}$. The runoff rate of the Pada River will not be influenced by mine dewatering in practice.

The predicted impact of mine dewatering is based on an assumption that the minewater outlets will be placed neither upstream from Sämi on the Kunda River nor in the upstream of the Selja River. Otherwise a significant portion of minewater pumped to the streams mentioned may return into the goaf under the influence of the downward hydraulic gradient in the area of the groundwater depression cone.

Scenario 2. Many boreholes and production wells percolate bedrock layers in the Pandivere Upland (Fig. 5). In places their spacing is quite dense, e.g. for the prospecting of the Kabala mine site a network of borings of about $200 \times 200 \mathrm{~m}$ was used. In some localities the distance between boreholes was only $100 \mathrm{~m}$. It is to be feared that many boreholes have remained unsealed or poorly sealed. If the heads of aquifers are different, a groundwater flow between aquifers takes place through open boreholes.

Numerous production wells having only their upper portion cased act in the same way. The man-made groundwater circulation was probably most intensive after the boring of holes, but it has decreased gradually in the course of time in accordance with the equalization of heads. The flow through many holes has likely ceased due to their clogging with clayey particles.

The mine dewatering may significantly change the situation described. If the difference between the heads of the upper and lower aquifers increases, strong downward fluxes may be generated in open boreholes. The holes penetrating the Oandu aquitard have special relevance for mine dewatering. They may conduct a remarkable amount of water from the overlying Nabala-Rakvere aquifer directly into the goaf.

To take into account the impact of open boreholes on the mine dewatering, the leakage factor $B$ of the Oandu aquitard was increased in the course of pumping simulated. The value of $B=0.0011 / \mathrm{d}$ was automatically assigned to these model nodes where the difference between the heads of the upper and lower aquifers exceeded the head difference recorded before pumping. In places the assigned value of $B$ outnumbered its initial value by up to three hundred times. Therefore the simulated downward groundwater flow from the upper model layer into the lower one increased significantly. 


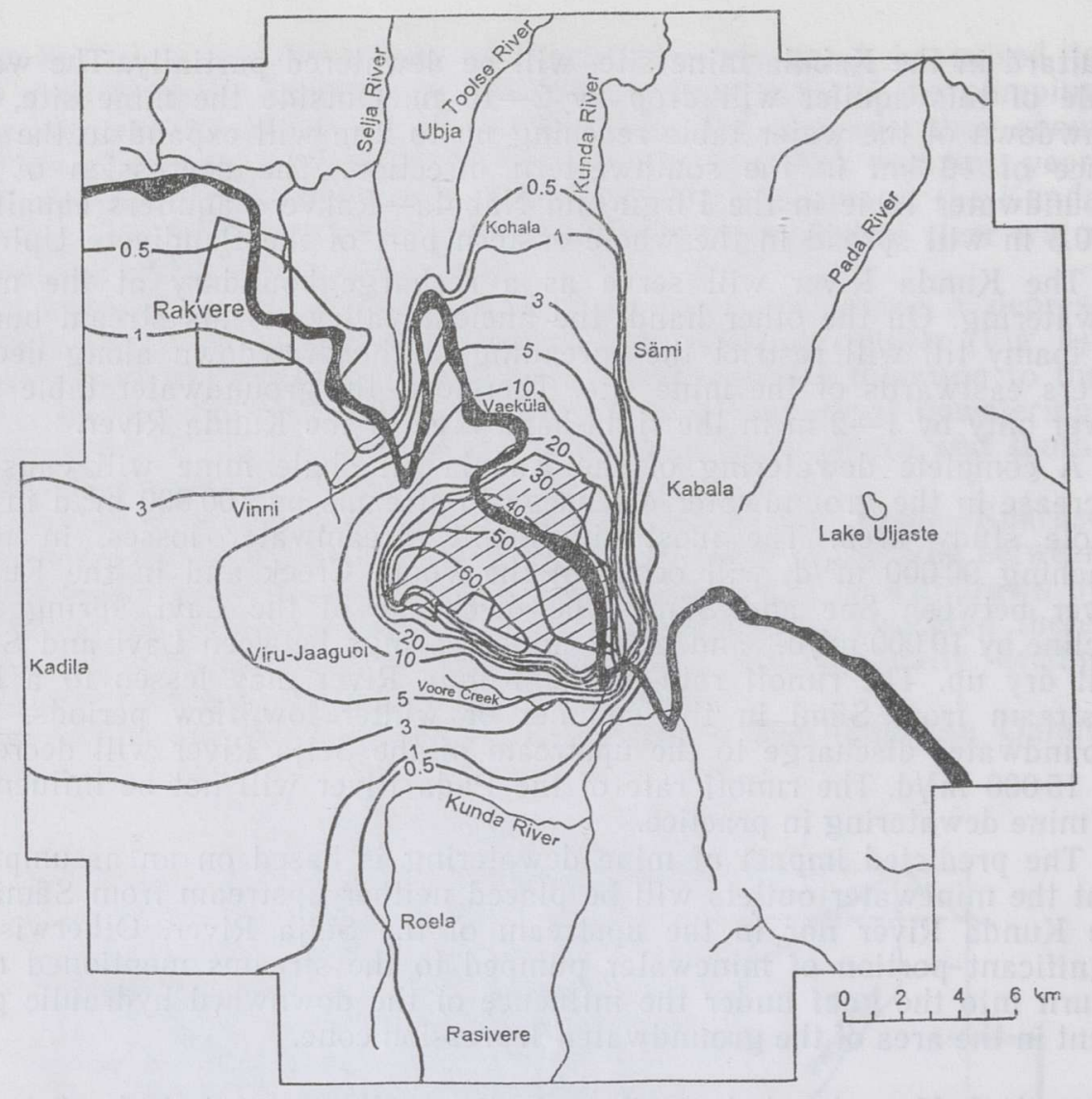

Fig. 5. Drawdown in groundwater level at high permeability of the Oandu aquitard and mine roof. Isolines - drawdown contours in both Nabala-Rakvere and Keila-Kukruse aquifers, $\mathrm{m}$.

The simulations carried out in accordance with scenario 2 indicated that the downward flow through the Oandu aquitard would be about $110000 \mathrm{~m}^{3} / \mathrm{d}$. It is approximately twice as much as at scenario 1 . The total amount of water pumped out from the mine will rise to $160000 \mathrm{~m}^{3} / \mathrm{d}$ in the 40th dewatering year. Owing to the increase in downward fluxes, the head depression in the confined portion of the Keila-Kukruse aquifer outside the mine site will be lesser than at scenario 1 (Fig. 5). In contrast, the unconfined Nabala-Rakvere aquifer will be completely dewatered in the mine site. Simulated drawdowns of the upper and lower model layers were almost equal. Therefore, the drawdown contours of both model layers are not differentiated in Fig. 5.

Scenario 2 may not be completely realized in practice. The joining impact of boreholes may be weaker than supposed or it may fully occur in the mine site only. However, a quite high probability of scenario 2 still exists, and simulations show what would happen if the values of the leakage factor $B$ increase during the pumping.

Besides groundwater, a remarkable amount of surface water may intrude directly into the goaf through ventilation shafts, unsealed boreholes, and open bedrock fissures. This portion of the inflow should also be taken into account at the mine dewatering calculations. However, more detailed forecasts of the dewatering budget are still premature. They will depend on the prospective mining technology, but this problem is not settled yet. 
Mine dewatering will evoke several disadvantageous phenomena. One of them is the decrease in the yield or even drying up of many shallow wells. Dug into Quaternary sediments or hewed into carbonate bedrock, they are commonly only by a half a metre deeper than the lowest groundwater table in natural conditions. A groundwater drawdown of only $0.5 \mathrm{~m}$ caused by mine dewatering may unfit these wells to water supply in dry periods. In the areas suffering from a greater drawdown, the dug wells will be out of use during a longer period or they will dry up completely. The bored wells recharging from the carbonate bedrock will be influenced to a lesser degree. Because of the lowering of the static water level in bored wells, their pumps may need a deeper set to guarantee the discharge rates required. However, to do this may in some cases be quite troublesome. On the whole, the construction of additional wells and reconstruction of the existing ones is necessary for a satisfactory drinking water supply in the area of the groundwater depression.

The hydraulic gradients and velocities of subsurface flows will increase because of mine dewatering. Directions of the groundwater movement will change. The still existing pollution sources may activate and pollution transport will accelerate. As a result, many water wells kept pure so far, may become contaminated.

The uneven subsidence of the mine roof will cause deformation of the ground surface. The formed closed depressions will have a relative depth of up to $1-2 \mathrm{~m}$. Deformation of the ground surface will balk at tillage and hinder the surface water runoff. An intensive water circulation may lead to the forming of new sinkholes in the carbonate bedrock.

The water pumped out from the Kabala oil shale mine will be enriched by sulphates due to intensive oxidation of pyrite in the man-made zone of aeration. Therefore, the content of the sulphate ion may reach $500 \mathrm{mg} / \mathrm{l}$ in minewater (in natural conditions the content of $\mathrm{SO}_{4}^{2-}$ does not exceed $50 \mathrm{mg} / \mathrm{l})$. Minewater will likely be polluted by oil leaking from mining machines, and will contain a lot of suspended clayey matter. The water will be extremely hard (up to $875 \mathrm{mg} / 1$ as $\mathrm{CaCO}_{3}$ ). In Estonian oil shale mines many serious underground fires have occurred causing the minewater pollution by phenol (Vallner \& Sepp, 1993). A similar danger exists also for the Kabala site. Minewater will not be suitable for drinking: without purification.

As a result of mining, spoil heaps will appear. They will contain oil shale residues tending to self-ignite in the presence of oxygen. The products of spontaneous burning (distilled oils, phenol, tar, etc.) are washed out by rainwater, and in the end they may intrude into aquifers and streams.

A decrement of the surface water runoff in the area of groundwater depression will worsen the biological self-regulation ability of streams. It may lead to unfavourable changing of their hydrochemical regime. If the water pumped out from mine is not purified well enough, the rivers will be heavily polluted downstream from minewater outlets.

\section{CONCLUSIONS}

The aquifer modelling study revealed that the maximum pumping rate for dewatering the proposed underground Kabala oil shale mine would be $96000-160000 \mathrm{~m}^{3} / \mathrm{d}$ depending on vertical permeability of the mine roof. Mine dewatering will cause a drawdown of the groundwater table ranging from 0.5 to $40 \mathrm{~m}$ in the Pandivere Upland and on its northern outskirts. The construction of additional wells and the reconstruction of 
the existing ones is necessary to guarantee the satisfactory drinking water supply in the area of the groundwater depression covering about $1000 \mathrm{~km}^{2}$.

Upstream from minewater outlets the runoff rate of streams will decrease by about $100000 \mathrm{~m}^{3} / \mathrm{d}$. This will worsen the biological self-regulation ability of streams. The minewater will be polluted by sulphate and oils; it will contain a lot of suspended clayey matter. The minewater should not be pumped into streams without purification.

\section{REFERENCES}

Anderson, M. \& Woessner, W. 1992. Applied Groundwater Modeling. Academic Press Incorporation, San Diego.

Estonian Mineral Resources. 1994. Ministry of the Environment of Estonia, Tallinn.

Lerner, D. N., Issar, A. S. \& Simmers, I. 1990. Groundwater Recharge. International Contribution to Hydrogeology, vol. 8. International Association of Hydrogeologists. Verlag Heinz Heise, Hannover.

Vallner, L. 1982. Pinnasevee taseme režiim Eestis. - In: Saarse, L. (ed.). Geograafia rakenduslikke aspekte põllumajanduses. Eesti Maaviljeluse ja Maaparanduse Teadusliku Uurimise Instituut, Tallinn-Saku, 86-91.

Vallner, L. \& Sepp, K. 1993. Effects of pollution from oil shale mining in Estonia. Land Degradation \& Rehabilitation, 4, 4, 381-385.

Vallner, L. 1994. Problems of groundwater quality management in Estonia. - In: Kovar, K. \& Soveri, J. (eds.). Groundwater Quality Management. IAHS (International Association of Hydrological Sciences) Publication No. 220, Wallingford, $449-460$.

van der Heijde, P. \& Elnawawy, O. 1993. Compilation of Groundwater Models. U.S. Environmental Protection Agency, Ada.

Woessner, W. W. \& Anderson, M. P. 1990. Setting calibration targets and assessing model calibration. - In: Kovar, K. (ed.). Calibration and Realibility in Groundwater Modelling. IAHS (International Association of Hydrological Sciences) Publication No. 195, Wallingford, 279-288.

Валлнер Л. К. 1980. Геогидродинамическая расчлененность и баланс подземных вод Эстонии. -In: Валлнер Л. Қ., Иыгар П. Э. (eds.). Проблемы гидрогеологии Эстонин. АН ЭССР, Таллинн, $11-120$.

Валлнер Л., Ныгар П1., Перенс Р. 1987. Гидрогеология. - In: Пуура В. (еd.). Геология и полезные ископаемые Раквереского фосфоритоносного района. Валгус, Таллинн, $104-127$.

Газизов М. С. 1971. Қарст и его влияние на горные работы. Недра, Москва.

Норватов Ю. А. 1988. Изучение и прогноз техногенного режима подземных вод. Недра, Ленинград.

Перенс Р. 1978. О применении расходометрии при расчленении гидрогеологического разреза карбонатной толщи на Пандивереской возвышенности. - Изв. АН ЭССР. Геол., 27, 4, 130-139.

Перенс Р. М. 1984. Изучение фильтрационных свойств силурийско-ордовикской карбонатной толщи Эстонии с помощью расходометрии. - In: Валлнер Л. K. (ed.). Методы анализа и обработки гидрогеологических данных для прогноза ресурсов подземных вод. АН ЭССР, Таллинн, 100-103.

Пуура В., Қаттай В., Раудсеп Р., Тээдумяэ А. 1987. Проблемы освоения и рационального использования полезных ископаемых. - In: Пуура В. (еd.). Геология и полезные ископаемые Раквереского фосфоритоносного района. Валгус, Таллинн, $179-190$. 
Раудсеп Р. и др. 1989. Отчет о результатах детальной разведки фосфоритов шахтного поля на месторождении Кабала Раквереского фосфоритоносного района Эстонской ССР, проведенной в 1985-89 гг. Эстонское производственное объединение по геологоразведочным работам. (Рукопись в Эстонском геологическом фонде.)

Саадре Т. и др. 1984. Отчет о комплексной геолого-гидрогеологической съемке масштаба 1:50000 и доизучение ранее заснятой площади Раквереского фосфоритоносного района. Управление геологии ЭССР. (Рукопись в Эстонском геологическом фонде.)

\title{
KARSTUNUD PANDIVERE KÕRGUSTIKULE KAVANDATUD KAEVANDUSE KUIVENDAMISE HUDROGEOLOOGILINE MODELLEERIMINE
}

\author{
Leo VALLNER
}

Kabala põlevkivikaevandus on kavandatud Pandivere kõrgustiku nõlvale, kus aluspõhi koosneb tugevasti karstunud karbonaatkivimitest. Mittestatsionaarse geofiltratsiooni kvaasi-kolmemõõtmeline modelleerimine näitas, et Kabala allmaakaevanduse kuivendamiseks peab sellest välja pumbatava põhjavee hulk olema 96000 kuni $160000 \mathrm{~m}^{3} / \mathrm{d}$. Pumpamishulk sõltub kaevanduse laekivimite läbilaskvusest. Kuivendamise tõttu alaneb põhjavee vabapind $0,5-40 \mathrm{~m}$ võrra ligikaudu $1000 \mathrm{~km}^{2}$ suurusel alal. Põhja- ja pinnavesi võivad kaevanduse piirkonnas ja sealt allavoolu oluliselt reostuda.

\section{ГИДРОГЕОЛОГИЧЕСКОЕ МОДЕЛИРОВАНИЕ ОСУШЕНИЯ ШАХТЫ НА ЗАКАРСТОВАННОЙ ПАНДИВЕРЕСКОЙ ВОЗВЫШЕННОСТИ, СЕВЕРО-ВОСТОЧНАЯ ЭСТОНИЯ}

\section{Лео ВАЛЛНЕР}

Намеченный под разработку участок сланцевой шахты Қабала расположен на склоне Пандивереской возвышенности, сложенной сильно закарстованными коренными породами. Қвазитрехмерное моделирование нестационарной геофильтрации показало, что для осушения этой шахты потребуется откачивать $96000-160000 \mathrm{~m}^{3}$ подземных вод в сутки. Дебит откачки определяется водопроницаемостью кровли шахтного пространства. Вследствие осушения шахты понижение уровня свободной поверхности подземных вод достигнет 0,5-40 м на площади около $1000 \mathrm{kM}^{2}$. В районе шахты и вниз от нее по течению поверхностные и подземные воды смогут подвергаться сильному загрязнению. 